\title{
Hanging as a method of suicide in Ghana: A 10 year autopsy study
}

\author{
Edmund M. Der ${ }^{1,3^{*}}$, Irene A. Dakwah'1 , Leonard Derkyi-Kwarteng ${ }^{2}$ and Akosa A. Badu
}

*Correspondence: maadelle@yahoo.com

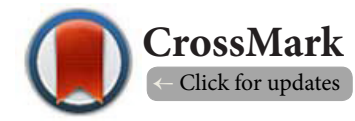

'Department of Pathology, School of Biomedical Sciences, Korle-Bu Teaching Hospital, Ghana. 2Department of Pathology, University of Cape Coast School of Medical Sciences, Cape Coast, Ghana. ${ }^{3}$ Department of Pathology, School of Medicine and Health Sciences, UDS Tamale, Northern, Ghana.

\begin{abstract}
Background: There are no official statistics on hanging as a method of suicide in Ghana. The aim of this study was to describe the proportions of deaths that were due to suicide by hanging, the gender and age characteristics and the type of ligature used and offer recommendations.

Material and methods: This was a retrospective autopsy study from 2003 to 2013 in our institution.

Results: About $0.34 \%$ of all autopsies performed were suicide by hanging. The male: female ratio was 7:1. The mean age of male victims was 35.6 years and that of females was 28.4 years. The modal age group of the females was 10-19 years (33.3\%) while that of the males was 20-29 years (29.6\%). There were no significant age differences between Male and female $(\mathrm{p}=0.08)$, male and the total study population $(\mathrm{p}=0.08)$ and also between female and the total population $(\mathrm{p}=0.73)$. The commonly used ligature by males was a nylon rope (46.9\%), while that for female was electric cable (27.8\%). In all $23.0 \%$ males and $33.3 \%$ females had no stated ligature used. For both males (52.3\%) and females (22.2\%) the common point of suspension was the branch of a tree. Many of the females have no stated point of suspension (55.6\%). There were significant differences with regards to the type of ligature used and the point of suspension between male and female ( $\mathrm{p}=0.018)$, male and the total study population $(\mathrm{p}=0.013)$ and also between female and the total study population $(\mathrm{p}=0.014)$. The reasons for suicide by hanging were not stated. There was a case each from the prison custody and the psychiatry hospital in Accra respectively.

Conclusion: The study found that $0.34 \%$ of all autopsies performed were suicide by hanging. The victims were mostly younger males. The commonly used ligature was a nylon rope, with tree branch as the point of suspension. As suicide by hanging is becoming common in Ghana, there is the need to develop strategies for its prevention.
\end{abstract}

Keywords: Suicide, hanging, Ghana, autopsy, ligature

\section{Introduction}

Hanging is one of the most commonly used fatal method of suicide worldwide [1-3]. Suicide rates vary by countries, age, gender, marital status, ethnicity and socioeconomic status $[4,5]$. The ligature mark and its characteristics is the most relevant feature of hanging at autopsy, even in instances where the ligature material is not available during autopsy. The incidence of hanging as a method of suicide is found to be on the rise in developed countries such as the United States of America and the United Kingdom [6-8].

Emerging evidence from the print and electronic media in Ghana have shown that hanging is becoming a common method of suicide especially among the productive age group $[9,10]$. However, there are no official statistics on hanging as a method of suicide [10-12]. The aim of this study was to describe the proportions of deaths due to suicide by hanging, the gender and age characteristics and the type of ligature used, by a descriptive autopsy data and offer recommendations. 
Der et al. Pathology Discovery 2016,

\section{Material and methods}

Study design

This was a retrospective descriptive autopsy study.

\section{Study site}

This study was conducted in the Korle-Bu Teaching Hospital Mortuary, the largest mortuary in the country Ghana, where between 3,000 and 6,000 autopsies are performed each year. This mortuary receives cases from the Korle-Bu teaching hospital, the largest referral hospital in Ghana; other hospitals within the Accra Metropolis, neighbouring towns and Districts. It also performs most coroners' autopsies in the southern half of the country.

\section{Data collection and analysis}

Autopsy log books, autopsy sheets and the coroner request forms for the period January 2003 through December 2013, were reviewed by two pathologists for the following: age and sex of the victim, location of death, reasons for hanging if available, type of ligature and point of suspension and the autopsy findings. Data were entered into a computerized spreadsheet and analyzed using SPSS software (Version 20). Frequency distributions and descriptive statistics were calculated for each variable.

\section{Inclusion criteria}

1. All well preserved bodies.

2. All cases of suicide by hanging.

3. All cases with well-defined ligature marks.

\section{Exclusion criteria}

1. Suicide deaths not by hanging.

2. All cases without a ligature mark.

3. Poorly preserved bodies.

\section{Results}

During the period of study (2003-2013), the total number of autopsies performed in our institution was 44,000, of which $148(0.34 \%)$ were deaths due to suicide by hanging. A total of $130(87.8 \%)$ of the victims were males with $18(12.2 \%)$ females. The male: female ratio was approximately $7: 1$. The age range of the entire study population was 11 to 75 years with a mean age of 34.7 years $(S D=14.1)$ and a modal age group of $20-29$ years $(28.7 \%)$. The age range for the male victims was $11-75$ years, mean age of 35.6 years $(S D=14.0)$ and modal age group of 20-29 years (29.6\%). The age range for the females was $12-52$, mean age of 28.4 years $(S D=13.5)$ and modal age group 12-19 (33.3\%) years (Table 1 and Figure 1). While about $41.2 \%$ of the entire study population was less than 30 years old, $39.2 \%$ males and $55.5 \%$ females respectively were less than 30 years of age. A total of 5 males have no stated age at the time of data collection. There were no significant age differences between Male and female $(p=0.08)$ male and the total study population $(p=0.08)$ and also between female victims and the total population ( $p=0.73$ ) (Tables $1 \mathrm{a}, 1 \mathrm{~b}$ and Figure 1 ).

The commonly used ligature for the male victims was a nylon rope (43.9\%). The commonly used ligature for the females was an electric cable 5 (27.8\%). About $24.3 \%$ of the male and $33.3 \%$ female victims had no stated ligature used (Table 2).

Table 1a. Age distribution of victims of suicide by hanging.

\begin{tabular}{llll}
\hline $\begin{array}{l}\text { Age group } \\
\text { (years) }\end{array}$ & Males (n/\%) & Females (n/\%) & Total (n/\%) \\
\hline$\leq 19$ & $12(9.6)$ & $6(33.3)$ & $18(12.6)$ \\
$20-29$ & $37(29.6)$ & $4(22.2)$ & $41(28.7)$ \\
$30-39$ & $31(24.8)$ & $5(27.8)$ & $36(25.1)$ \\
$40-49$ & $24(19.2)$ & $0(0.0)$ & $24(16.8)$ \\
$50-59$ & $12(9.6)$ & $3(16.7)$ & $15(10.5)$ \\
$\geq 60$ & $9(7.2)$ & $0(0.0)$ & $9(6.3)$ \\
Total & $125(100.0)$ & $18(100.0)$ & $143(100.0)$ \\
\hline
\end{tabular}

Table 1b. Paired differences test of victims of suicide by hanging.

\begin{tabular}{lllllllll}
\hline \multicolumn{10}{c}{ Mean } & $\begin{array}{l}\text { Std. } \\
\text { Deviation }\end{array}$ & $\begin{array}{l}\text { Std. Error } \\
\text { Mean }\end{array}$ & \multicolumn{2}{l}{$\begin{array}{l}\text { 95\% Confidence Interval } \\
\text { of the Difference }\end{array}$} & t & df & P-values \\
& & & & Lower & Upper & & & \\
\hline Male-Female & 15.28571 & 30.14478 & 8.05653 & -2.11936 & 32.69079 & 1.897 & 13 & 0.080 \\
Male-Total & -2.57143 & 5.07413 & 1.35612 & -5.50115 & 0.35829 & -1.896 & 13 & 0.080 \\
Female-Total & -17.85714 & 34.27728 & 9.16099 & -37.64825 & 1.93397 & -1.949 & 13 & 0.073 \\
\hline
\end{tabular}

There are no significant differences between Male, Female and Total victims of suicide by hanging among the various age groups since the p-values $0.08,0.80$ and 0.73 are greater 0.05 . 
Table 2a. Type of ligature used and the point of suspension in suicide.

\begin{tabular}{llll}
\hline & Male $(\mathbf{n} / \%)$ & Female (n/\%) & Total (n/\%) \\
\hline Ligature used & & & \\
\hline Nylon robe & $61(46.9)$ & $4(22.2)$ & $65(43.9)$ \\
Sponge & $3(2.3)$ & $1(5.6)$ & $4(2.7)$ \\
Cloth & $0(0.0)$ & $2(11.1)$ & $2(1.4)$ \\
Belt & $10(7.7)$ & $0(0.0)$ & $10(6.8)$ \\
Electric cable & $26(20.0)$ & $5(27.8)$ & $31(20.9)$ \\
Not stated & $30(23.0)$ & $6(33.3)$ & $36(24.3)$ \\
Total & $130(100.0)$ & $18(100.0)$ & $148(100.0)$ \\
\hline Point of suspension & & & \\
\hline Tree branch & $68(52.3)$ & $4(22.2)$ & $72(48.6)$ \\
Ceiling of a root & $30(23.0)$ & $3(16.7)$ & $33(22.3)$ \\
Door handle & $0(0.0)$ & $1(5.6)$ & $1(0.7)$ \\
Not stated & $32(24.6)$ & $10(55.6)$ & $42(28.4)$ \\
Total & $130(100.0)$ & $18(100.0)$ & $148(100.0)$ \\
\hline
\end{tabular}

Table 2b. Paired differences of ligature used and the point of suspension in suicide.

\begin{tabular}{|c|c|c|c|c|c|c|c|c|}
\hline \multicolumn{9}{|c|}{ Paired Differences } \\
\hline & \multirow[t]{2}{*}{ Mean } & \multirow[t]{2}{*}{$\begin{array}{l}\text { Std. } \\
\text { Deviation }\end{array}$} & \multirow[t]{2}{*}{$\begin{array}{l}\text { Std. } \\
\text { Error Mean }\end{array}$} & \multicolumn{2}{|c|}{$\begin{array}{l}\text { 95\% Confidence Interval of } \\
\text { the Difference }\end{array}$} & \multirow[t]{2}{*}{$\mathrm{t}$} & \multirow[t]{2}{*}{ df } & \multirow[t]{2}{*}{ P-values } \\
\hline & & & & Lower & Upper & & & \\
\hline Male-Female & 18.65417 & 35.70958 & 7.28919 & 3.57533 & 33.73300 & 2.559 & 23 & 0.018 \\
\hline Male-Total & -3.00833 & 5.44673 & 1.11181 & -5.30829 & -0.70838 & -2.706 & 23 & 0.013 \\
\hline Female-Total & -21.66250 & 39.96307 & 8.15743 & -38.53742 & -4.78758 & -2.656 & 23 & 0.014 \\
\hline
\end{tabular}

There are significant differences between Male, Female and Total victims of suicide by hanging in terms of ligature used and the point of suspension in suicide since the p-values $0.018,0.013$ and 0.014 are less than 0.05 .

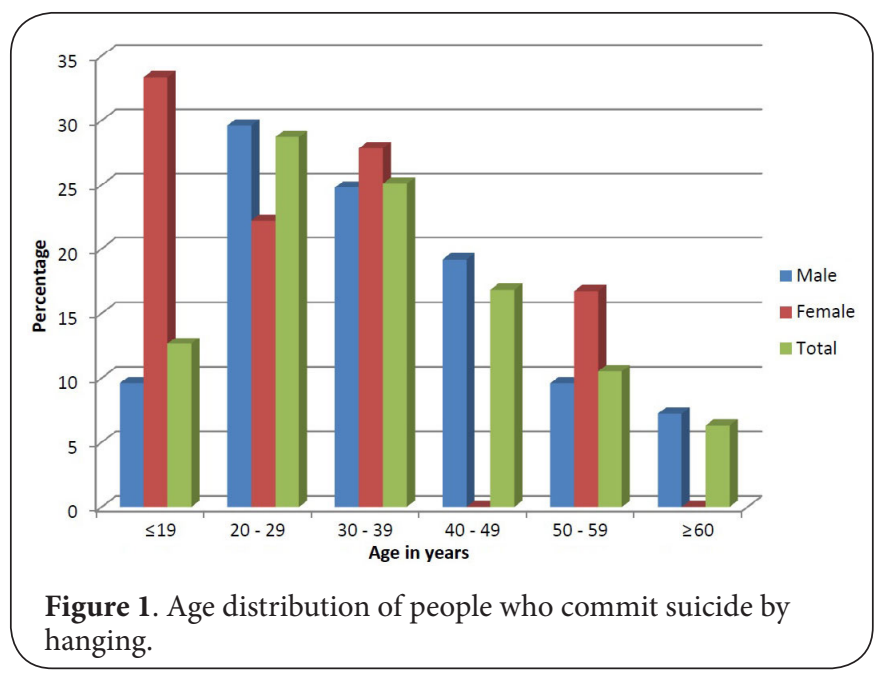

The common point of suspension for both males $(48.6 \%)$ and females (22.2\%) was the branch of a tree. Many (55.6\%) of the female victims had no stated point of suspension. Deaths in males were by complete suspension (100.0\%). A total of
$16(88.9 \%)$ of the female deaths were complete suspension, while $2(11.1 \%)$ were incomplete, consisting of hanging by the door handle and a tree branch respectively. There were significant differences with regards to the type of ligature used and the point of suspension between male and female $(p=0.018)$, male and the total study population $(p=0.013)$ and also between female and the total study population $(p=0.014)$ (Tables $2 \mathrm{a}$ and $\mathbf{2 b}$ ).

The reasons why victims committed suicide by hanging in this study were not stated in any of the cases, but there was a case each from the prison custody (male, using a sponge) and the psychiatry hospital (male, ligature not stated) in Accra respectively.

\section{Discussion}

The story of suicide is probably as old as man himself. Suicide by hanging has cultural, religious and criminal implications to the community in which the act was committed and to the victim's household, although it is said to be a private and a personal act. According to WHO hanging is the commonly used method of suicide in the developed $[1,2]$ and developing countries [3]. The rates vary by country, socioeconomic and 
Der et al. Pathology Discovery 2016,

the sociocultural status of the individual $[4,5]$. In this study, it was found that $0.34 \%$ of all autopsies performed in our institution were suicide deaths by hanging, there was no trend in the numbers of suicide deaths over the study of period. This differs from studies in the United States of America (USA) [6] and the United Kingdom (UK) $[7,8]$ that found rising trend in the number of persons who commit suicide by hanging. Actual data on suicide death by hanging in Ghana as indicated by the Ghana Statistical Service is scanty [9] and are mostly by the medical sociologists and the Psychiatrists [10-12]. Therefore a rate of $0.34 \%$ in this current study is deemed significant, judging from the fact that this was the first institution-based autopsy study in Ghana with no previous autopsy statistics to compare with. The lack of data or the low rates of hanging as a method of suicide in our country can partly be attributed to the taboos and criminality ascribed to death by hanging in our society $[13,14]$ and this create fertile ground for under reporting of suicide related deaths as mentioned in previous studies in Ghana and other countries $[15,16]$.

In this current study it was found that suicide by hanging was more common in the younger age groups with mean age of 34.7 years ( $S D=14.1)$ and a modal age group of 20-29 years. This is similar to studies by Quarshie et al., in Ghana, [10] and Stark et al., in Scotland [17], who found younger age group to commonly commit suicide by hanging. The current findings however differ from studies in the United States of America that found the act to be more common in the middleaged adults [18-20]. The great majority of suicide deaths in this study were males, with male - female ratio of $7: 1$. This is similar to studies that found the male gender to commonly commit suicide by hanging [21-25].

For any individual to successfully commit suicide by hanging no matter the geographical location or level of education, access to a ligature is an important factor that leads the person to suicidal action $[\mathbf{2 5}, \mathbf{2 6}]$. In this study victims committed suicide using every day common items such as; ropes, belts, electric cables, sponge and cloths. This spectrum of ligatures used are similar to those found in other autopsy studies [2630]. The common points of suspension in this study were tree branches and the ceiling of the roof, a finding that is similar to the study of Vipul et al., [27] and Oliver et al., [31] This study also found that $98.6 \%$ of the hangings were complete, a value higher than the $50 \%$ found by Olive et al., [31] and the $67.7 \%$ found in Vipul et al., autopsy study [27]. This value is however closer to $97.2 \%$ found in Ahmed et al., autopsy study [32].

The reasons why individuals commit suicide are heterogeneous, multifactorial and not a consequence of a single cause or stressor. These include psychosocial and psychiatric factors, familial or genetic tendencies, childhood experiences and underlying metabolic conditions $[31,33]$. Studies have shown that in about $25 \%$ to $30 \%$ of suicide victims leave a note, stating the reasons for the act $[34,35]$. Unfortunately, in this current institutional based study, there were no reasons for the act. This may be due to the fact that the study was a retrospective study and also because the act is considered by culture to be an abomination and punishable by the laws of the country and also by God.

This study found that $1.4 \%$ of the deaths occurred in the prison custody and the psychiatric hospital in Accra respectively. Although a smaller value compared to the $6.0 \%$ found in Oliver et al., study [31], it supports studies that found hanging as a common method of suicides in these settings, these deaths could have prevented by having a ligature free environment [36,37].

\section{Limitations}

1. Incomplete autopsy reports by the pathologist.

2. Scanty history provided by relatives and the police investigators.

3. In some cases the ligatures are removed before the body is brought for autopsy.

\section{Recommendations}

Commitment by the Ghana government to establish and implement coordinated plans of action, including paying attention to mental health care services in the country. This will reduce deaths by suicide.

Involvement by the society in addressing this public health problem which has been shrouded in taboo for far too long. Provision of traditional support systems in the country especially the economic and social values must be strengthened to help reduce incidence of suicide in Ghana.

To decriminalize the law (1960 criminal act 29 section 57) criminalizing attempted suicide in Ghana.

\section{Conclusion}

The study found that $0.34 \%$ of all autopsies performed were deaths due to suicide by hanging. The victims were mostly younger male with male: female ratio of 7:1. The commonly used ligature was a nylon rope with the tree branch as the point of suspension. As suicide by hanging is becoming common in Ghana, there is the need to develop strategies for its prevention.

\section{Competing interests}

The authors declare that they have no competing interests.

\section{Authors' contributions}

\begin{tabular}{|l|c|c|c|c|}
\hline Authors' contributions & EMD & IAD & LKD & AAB \\
\hline Research concept and design & $\checkmark$ & -- & -- & -- \\
\hline Collection and/or assembly of data & $\checkmark$ & $\checkmark$ & $\checkmark$ & -- \\
\hline Data analysis and interpretation & $\checkmark$ & $\checkmark$ & $\checkmark$ & -- \\
\hline Writing the article & $\checkmark$ & -- & -- & $\checkmark$ \\
\hline Critical revision of the article & $\checkmark$ & $\checkmark$ & $\checkmark$ & -- \\
\hline Final approval of article & $\checkmark$ & $\checkmark$ & $\checkmark$ & $\checkmark$ \\
\hline Statistical analysis & $\checkmark$ & -- & -- & -- \\
\hline
\end{tabular}

\section{Acknowledgement}

Thanks to all residents and the biomedical staff of the department of pathology for their support. 
Der et al. Pathology Discovery 2016,

\section{Publication history}

Editors: Hiroko Kuwabara, Osaka Medical College, Japan. George Perry, University of Texas at San Antonio, USA.

Received: 10-Mar-2016 Final Revised: 20-Apr-2016

Accepted: 13-May-2016 Published: 19-May-2016

\section{References}

1. World Health Organization. Adolescence: An age of opportunity. Geneva. 2011.

2. Gunnell D, Bennewith O, Hawton K, Simkin S and Kapur N. The epidemiology and prevention of suicide by hanging: a systematic review. Int J Epidemiol. 2005; 34:433-42. | Article | PubMed

3. Accidental Deaths and Suicides in India. New Delhi: Ministry of Home Affairs, Government of India. National Crime Records Bureau. 2008.

4. Ayash-Abdo H. Adolescent suicide: An ecological approach. Psychology in Schools. 2002; 39:459-475. | Article

5. Osafo J, Hjelmeland H, Akotia C.S and Knizek B.L. The Meaning(s) of Suicidal behaviour to Psychology students: A Qualitative Approach to Understanding Suicidal Behaviour in Ghana. Journal of Transcultural Psychiatry. 2011; 48:1-17. | Article

6. Suicide in the U.S. Statistics and Prevention. National Institute of Mental Health. 2011.

7. National Suicide Prevention Strategy for England. London: Department of Health. 2002.

8. Brock $A$ and Griffiths $C$. Trends in suicide by method in England and Wales, 1979 to 2001. Health Statistics Quarterly. 2003; 20:7-18.

9. Ghana Statistical Service (GSS). Population \& housing census report: Children, adolescents and young people in Ghana. Accra. 2013.

10. Quarshie E.N.B. Osafo J, Akotia C.S and Peprah J. A content analysis of media reports. Int J Qual Stud Health Well-being. 2015; 10. I Article

11. Eshun S. Sociocultural determinants of suicide ideation: a comparison between American and Ghanaian college samples. Suicide Life Threat Behav. 2003; 33:165-71. | Article | PubMed

12. Knizek BL, Akotia CS and Hjelmeland $\mathrm{H}$. A qualitative study of attitudes toward suicide and suicide prevention among psychology students in Ghana. Omega (Westport). 2010; 62:169-86. | Article | PubMed

13. Mensah Adinkrah. Epidemiologic Characteristics of Suicidal Behavior in Contemporary Ghana. Crisis. 2011; 32:31-36. | Article

14. Appleby L, Shaw J and Sherratt J et al. Safety First: Five-year report of the National Confidential Enquiry into Suicide and Homicide by People with Mental Illness. London: Department of Health. 2001.

15. Hjelmeland H, Akotia C.S, Owens V, Knizek B.L, Nordvik H and Schroeder $\mathrm{R}$ et al. Suicide prevention among psychology students in Ghana, Uganda, and Norway. Crisis. 2008; 29:20-31.

16. Breiding MJ and Wiersema B. Variability of undetermined manner of death classification in the US. Inj Prev. 2006; 12 Suppl 2:ii49-ii54. | Article | PubMed Abstract | PubMed FullText

17. Stark C, Hopkins P, Gibbs D, Rapson T, Belbin A and Hay A. Trends in suicide in Scotland 1981 - 1999: age, method and geography. BMC Public Health. 2004; 4:49. | Article | PubMed Abstract | PubMed FullText

18. Phillips JA, Robin AV, Nugent $C N$ and Idler EL. Understanding recent changes in suicide rates among the middle-aged: period or cohort effects? Public Health Rep. 2010; 125:680-8. | PubMed Abstract | PubMed FullText

19. Baker SP, Hu G, Wilcox HC and Baker TD. Increase in suicide by hanging/ suffocation in the U.S., 2000-2010. Am J Prev Med. 2013; 44:146-9.. | Article | PubMed Abstract | PubMed FullText

20. CDC. Web-based Injury Statistics Query and Reporting System (WISQARS). I Website

21. Centers for Disease Control and Prevention. 2008.

22. First WHO report on suicide prevention. 2014.

23. Biddle L, Brock A, Brookes ST and Gunnell D. Suicide rates in young men in England and Wales in the 21st century: time trend study. BMJ. 2008; 336:539-42. | Article | PubMed Abstract | PubMed FullText

24. Wilkinson $D$ and Gunnell D. Comparison of trends in method-specific suicide rates in Australia and England \& Wales, 1968-97. Aust N Z J Public Health. 2000; 24:153-7. | Article | PubMed

25. Ajdacic-Gross V, Weiss MG, Ring M, Hepp U, Bopp M, Gutzwiller F and Rossler W. Methods of suicide: international suicide patterns derived from the WHO mortality database. Bull World Health Organ. 2008; 86:726-32. | Article | PubMed Abstract | PubMed FullText

26. Biddle L, Donovan J, Owen-Smith A, Potokar J, Longson D, Hawton K, Kapur $\mathrm{N}$ and Gunnell $\mathrm{D}$. Factors influencing the decision to use hanging as a method of suicide: qualitative study. Br J Psychiatry. 2010; 197:3205. | Article | PubMed

27. Vipul N.A, Nilesh T, Satin M and Jaydeo B. Ligature material in hanging deaths: The neglected area in forensic examination. Egyptian Journal of Forensic Sciences. 2015; 5:109-113. | Article

28. Saisudheer T and Nagaraja T.V. A study of ligature mark in cases of hanging deaths. Int J Pharm Biomed. 2012; 3:80-84.

29. Patel A.P, Bansal A, Sheikh I.V and Sheikh K.A. Study of hanging cases in Ahmedabad region. J Indian Acad Forensic Med. 2012; 34:342-345. | Pdf

30. Tumram NK, Ambade VN, Bardale RV and Dixit PG. Injuries over neck in hanging deaths and its relation with ligature material: is it vital? J Forensic Leg Med. 2014; 22:80-3. | Article | PubMed

31. Bennewith O, Gunnell D, Kapur N, Turnbull P, Simkin S, Sutton L and Hawton K. Suicide by hanging: multicentre study based on coroners' records in England. Br J Psychiatry. 2005; 186:260-1. | Article | PubMed

32. Ahmad M and Hossain M.Z. Hanging as a method of suicide: Retrospective analysis of postmortem cases. J AFMC, Bangladesh. 2010; 6:37-39. | Pdf

33. Health Canada. Suicide in Canada: Update of the report of the task force on suicide in Canada. 1994

34. Pompili M, Innamorati M, Girardi P, Tatarelli R and Lester D. Evidencebased interventions for preventing suicide in youths. In: Pompili $M$, Tatarelli R, editors. Evidence based practice in suicidology: A source book. Gottingen: Hogrefe. 2011; 173-209.

35. Weir $\mathrm{E}$ and Wallington T. Suicide: the hidden epidemic. CMAJ. 2001; 165:634-636. | Article | PubMed Abstract | PubMed FullText

36. Burrows T, Brock A.P and Hulley $S$ et al. Safer Cells Evaluation: Full Report. London: The Jill Dando Institute of Crime Science, University College London. 2003.

37. Moscicki EK. Epidemiology of completed and attempted suicide: Toward a framework for prevention. Clinical Neuroscience Research. 2001; 1:310-23. | Article

\section{Citation:}

Der EM, Dakwah IA, Derkyi-Kwarteng L and Badu AA. Hanging as a method of suicide in Ghana: A 10 year autopsy study. Pathol Discov. 2016; 4:2.

http://dx.doi.org/10.7243/2052-7896-4-2 